\title{
Deficiency of GDNF Receptor GFR $\alpha 1$ in Alzheimer's Neurons Results in Neuronal Death
}

\author{
Yoshihiro Konishi, ${ }^{1,4}$ Li-Bang Yang, ${ }^{1}$ Ping He, ${ }^{1}$ Kristina Lindholm, ${ }^{1}$ Bai Lu, ${ }^{3}$ Rena Li, ${ }^{2,5}$ and Yong Shen ${ }^{1,6,7,8}$ \\ ${ }^{1}$ Haldeman Laboratory of Molecular and Cellular Neurobiology, and ${ }^{2}$ Center for Hormone Advanced Science and Education, Roskamp Institute, Sarasota, \\ Florida 34243, ${ }^{3}$ Section on Synaptic Development, National Institute of Child Health and Development, National Institutes of Health, Bethesda, Maryland \\ 20892, ${ }^{4}$ Department of Clinical Research, National Tottori Medical Center, Tottori 689-0203, Japan, ${ }^{5}$ Beijing Institute for Brain Disorders, Beijing, China \\ 100069, ${ }^{6}$ Center for Advance Therapeutics Strategies for Brain Disorders, Roskamp Institute, Sarasota, Florida 34243, ${ }^{7}$ Department of Neurology, \\ University of Florida College of Medicine, Gainesville, Florida 31620, and ${ }^{8}$ The School of Life Sciences and Medical Research Center, University of \\ Science and Technology, Hefei, Anhui 230027 China
}

We have recently developed aged cortical neuron cultures from autopsied human brains with Alzheimer's disease (AD). During the culturing process, we found that glutamatergic cortical neurons from the AD brain lacked a response to glial cell line-derived neurotrophic factor (GDNF), including no axonal regrowth, and were starting to undergo apoptosis. Here we showed that, in cortical neurons from age- and gender-matched cognitively normal control (NC) subjects (NC neurons), GDNF enhanced the expression of GDNF family receptor subtype $\alpha 1$ (GFR $\alpha 1$ ), but not the other three subtypes (GFR $\alpha 2$, GFR $\alpha 3$, and GFR $\alpha 4$ ), whereas GDNF failed to induce GFR $\alpha 1$ expression in cortical neurons from the AD brain (AD neurons). The exogenous introduction of GFR $\alpha 1$, but not of its binding partner $\alpha 1$-neural cell adhesion molecule, or RET into AD neurons restored the effect of GDNF on neuronal survival. Moreover, between NC and $\mathrm{AD}$ neurons, the AMPA receptor blocker CNQX and the NMDA receptor blocker AP-5 had opposite effects on the GFR $\alpha 1$ expression induced by GDNF. In NC neurons, the presence of glutamate receptors was necessary for GDNF-linked GFR $\alpha 1$ expression, while in AD neurons the absence of glutamate receptors was required for GFR $\alpha 1$ expression by GDNF stimulation. These results suggest that, in AD neurons, specific impairments of GFR $\alpha 1$, which may be linked to glutamatergic neurotransmission, shed light on developing potential therapeutic strategies for AD by upregulation of GFR $\alpha 1$ expression.

Key words: neurodegeneration; neuron

\section{Introduction}

The accumulation of $\beta$-amyloid ( $A \beta$ ) peptide is a primary characteristic in Alzheimer's disease (AD) pathogenesis. According to the amyloid hypothesis, alleviating $A \beta$-induced damage is one of the therapeutic strategies (Hardy and Selkoe, 2002); however, approaches based on the amyloid hypothesis have been challenged by the disappointing results of recent clinical studies

Received June 18, 2013; revised July 6, 2014; accepted Aug. 20, 2014.

Author contributions:Y.K., R.L., and Y.S. designed research; Y.K., L.-B.Y., P.H., and K.L. performed research;Y.K., L.-B.Y., P.H., and R.L. analyzed data; Y.K., L.-B.Y., P.H., K.L., B.L., R.L., and Y.S. wrote the paper.

This work was supported by National Institutes of Health Grants R01AG025888, R01032441, and R01025888S; by Arizona Biomedical Research Commission ABRC002; by the Alzheimer's Association Zenith Award II Initiated Research Grants IIRG-07-59510 and IIRG-09-61521 and New Investigator Research Grant NIRG-08-91471; by American Health Assistance Foundation Grant G2006-118; and a grant from the Research Resource Network (RRN) of the National organization in Japan.

B.L. works at GlaxoSmithKline (GSK) Pharmaceutical. The remaining authors declare no competing financial interests.

Correspondence should be addressed to either of the following: Yong Shen, The Roskamp Institute, 2040 Whitfield Avenue, Sarasota, FL 34243, E-mail: yshen@rfdn.org; or Rena Li, Center for Hormone Advanced Science and Education, Roskamp Institute, Sarasota, FL 34243, E-mail: rli@rfdn.org.

Y. Konishi's present address: Research Unit for Alzheimer's Disease, Department of Clinical Research, National Tottori Medical Center, Tottori 689-0203, Japan.

L.-B. Yang's present address: Department of Pediatrics, University of Minnesota, Minneapolis, MN 55445.

P. He's, K. Lindholm's, and Y. Shen's present address: The Roskamp Institute, Sarasota, FL 34243.

DOI:10.1523/JNEUROSCI.2582-13.2014

Copyright $\odot 2014$ the authors $\quad 0270-6474 / 14 / 3413127-12 \$ 15.00 / 0$
(Hardy, 2009). Although numerous hypothesis-based (including the amyloid hypothesis) disease-modifying drug candidates are still under development for clinical trials (Alzheimer's Association et al., 2011; Imbimbo et al., 2011), drug development efforts should be diversified to fully address the multifactoriality of the disease (Seabrook et al., 2007; Huang and Mucke, 2012). Given the past failure of monotherapies for $\mathrm{AD}$ treatments, it might be necessary to use a combination of different disease-modifying approaches [i.e., neurotrophic factor (NTF) therapy] to halt the different disease-causing mechanisms simultaneously (Weissmiller and $\mathrm{Wu}, 2012$ ), regardless of whether neuronal damage is primarily caused by $\mathrm{A} \beta$ or other mechanisms. Although this type of treatment is actually under development for clinical trials, it has not yet provided satisfactory outcomes to fulfill its potential as a neurorestorative therapy (Weissmiller and $\mathrm{Wu}, 2012$; Allen et al., 2013).

The potential use of NTFs, such as neurotrophins, including nerve growth factor and brain-derived neurotrophic factor, for the treatment of neurodegenerative diseases including $\mathrm{AD}$, has long been suggested (Siegel and Chauhan, 2000). Glial cell linederived neurotrophic factor (GDNF) is recognized as a potent NTF in the nervous system (Walton, 1999). GDNF family ligands, such as GDNF, signal through receptors consisting of RET (Treanor et al., 1996) and one of four ligand-binding proteins 
Table 1. Clinical and neuropathological characteristics of the NC subjects and AD patients

\begin{tabular}{|c|c|c|c|c|c|c|c|c|c|c|c|c|}
\hline & $\begin{array}{l}\text { Case } \\
\text { no. }\end{array}$ & Age (years)* & Gender & $\begin{array}{l}\text { PMl } \\
(\mathrm{h})^{*}\end{array}$ & $\begin{array}{l}\text { ApoE } \\
\text { allele }\end{array}$ & Clinical diagnosis & $\begin{array}{l}\text { Disease duration } \\
\text { (years) }\end{array}$ & $\begin{array}{l}\text { MMSE } \\
\text { score }\end{array}$ & $\begin{array}{l}\text { Neuropathological } \\
\text { summary }\end{array}$ & Brain weight $(\mathrm{g})^{* *}$ & $\begin{array}{l}\text { CERAD plaque } \\
\text { score }\end{array}$ & Braak staging \\
\hline \multirow[t]{6}{*}{$A D$} & $A D-1$ & 81 & M & 3 & $3 / 4$ & $A D$ & 13 & 6 & $A D$ & 1090 & Frequent & V \\
\hline & $A D-2$ & 76 & M & 2.3 & $3 / 3$ & $A D$ & 11 & 0 & $\begin{array}{l}A D \text {, cerebral white matter } \\
\text { rarefaction }\end{array}$ & 1045 & Frequent & VI \\
\hline & $A D-3$ & 79 & M & 2 & $3 / 3$ & $A D$ & 7 & 0 & $\begin{array}{l}A D \text {, cerebral white matter } \\
\text { rarefaction }\end{array}$ & 1110 & Frequent & V \\
\hline & $A D-4$ & 90 & $\mathrm{~F}$ & 3 & $3 / 3$ & $\begin{array}{l}\text { AD, osteoarthritis, } \\
\text { depression }\end{array}$ & 11 & 5 & $\begin{array}{l}\text { AD, cerebral white matter } \\
\text { rarefaction, hippocam- } \\
\text { pal sclerosis }\end{array}$ & 905 & Frequent & V \\
\hline & $A D-5$ & 89 & $\mathrm{~F}$ & 3 & $3 / 4$ & $A D$ & 10 & 0 & $\begin{array}{l}A D \text {, cerebral white matter } \\
\text { rarefaction in the } \\
\text { frontal cortex }\end{array}$ & 1010 & Frequent & V \\
\hline & $A D-6$ & 91 & $\mathrm{~F}$ & 3 & $3 / 3$ & $A D$ & 6 & 0 & $\begin{array}{l}\text { AD, argyrophilic grains in } \\
\text { the temporal cortex, } \\
\text { acute infarctions in the } \\
\text { right inferior temporal } \\
\text { and occipital cortex }\end{array}$ & 995 & Frequent & V \\
\hline \multirow[t]{6}{*}{ NC } & NC-1 & 85 & M & 3.2 & $3 / 3$ & Control & 0 & 30 & $\begin{array}{l}\text { Control, old lacunar and } \\
\text { microscopic infarcts in } \\
\text { the left postcentral } \\
\text { cortex }\end{array}$ & 1280 & None & $\|$ \\
\hline & NC-2 & 86 & $\mathrm{~F}$ & 2.5 & $3 / 3$ & $\begin{array}{l}\text { Control, chronic } \\
\text { lung fibrosis, } \\
\text { rheumatoid } \\
\text { arthritis }\end{array}$ & 0 & 27 & $\begin{array}{l}\text { Control, recent small } \\
\text { infarctions in the left } \\
\text { frontal, left temporal } \\
\text { cortex, old cortical } \\
\text { microinfarction in the } \\
\text { left precentral cortex, } \\
\text { argyrophilic grains in } \\
\text { mesial temporal cortex }\end{array}$ & 1145 & None & III \\
\hline & NC-3 & 88 & $\mathrm{~F}$ & 3 & $3 / 4$ & Control & 0 & 30 & $\begin{array}{l}\text { Normal brain showing } \\
\text { minimal age-related } \\
\text { changes }\end{array}$ & 1030 & None & $\|$ \\
\hline & NC-4 & 73 & M & 2 & $3 / 4$ & Control & 0 & 28 & $\begin{array}{l}\text { Control, brain showing } \\
\text { only normal aging } \\
\text { changes }\end{array}$ & 1410 & None & II \\
\hline & NC-5 & 86 & $\mathrm{~F}$ & 2 & $2 / 3$ & $\begin{array}{l}\text { Control, liver } \\
\text { cancer, right } \\
\text { leg thrombosis }\end{array}$ & 0 & 29 & $\begin{array}{l}\text { Control, brain showing } \\
\text { only normal aging } \\
\text { changes }\end{array}$ & 1150 & None & II \\
\hline & NC-6 & 78 & M & 1.7 & $3 / 3$ & Control & 0 & 28 & $\begin{array}{l}\text { Control, cerebral white } \\
\text { matter rarefaction and } \\
\text { gliosis in the right } \\
\text { temporal cortex }\end{array}$ & 1460 & None & I \\
\hline
\end{tabular}

M, Male; F, female; PMI, postmortem interval; MMSE, Mini-Mental State Examination; ApoE, apolipoprotein E.

${ }^{*}$ Not significantly different; ** $p<0.05$ between $A D$ and NC groups.

[GDNF family receptor subtype $\alpha 1$ (GFR $\alpha 1), \operatorname{GFR} \alpha 2$, GFR $\alpha 3$, and GFR $\alpha 4$; Rosenthal, 1999], in which GFR $\alpha 1$ preferentially binds to GDNF (Sariola and Saarma, 2003). GDNF uses the $\alpha 1$ neural cell adhesion molecule ( $\alpha 1$-NCAM)-dependent signaling pathway instead of the RET-dependent pathway, particularly in hippocampal and cortical neurons (Paratcha et al., 2003), which are vulnerable to $\mathrm{AD}$ pathology. Clinical use of GDNF for the treatment of Parkinson's disease is currently under trial (Ramaswamy et al., 2009), and GDNF has a high potential for therapeutic applications in neurologic disorders (Arenas, 1996); however, no study so far has addressed the role of GDNF in the treatment of $\mathrm{AD}$.

Here we isolated and cultured cortical neurons from autopsied elderly human brains (Konishi et al., 2002) and found a significant decrease in GFR $\alpha 1$ levels in $\mathrm{AD}$ neurons. The application of GFR $\alpha 1$ ligands, GDNF and artemin (Baloh et al., 1998), could not promote neurite growth or the cell survival of $\mathrm{AD}$ neurons, unlike the positive role of GDNF and artemin in normal control (NC) neurons. The introduction of GFR $\alpha 1$ into AD neurons under treatment with GDNF and artemin could improve cell survival.

\section{Materials and Methods}

Human subjects. All subjects or their legally authorized representatives signed an informed consent form for autopsy and research. The standard research protocol was approved by the Institutional Review Board. NC and $\mathrm{AD}$ brain tissues were obtained from the Sun Health Research Institute Brain and Body Donation Program (Beach et al., 2008). The subjects and patients consisted of six NC subjects ( $82.7 \pm 5.9$ years old, 3 males and 3 females $)$ and six patients with $\mathrm{AD}(84.3 \pm 6.4$ years old, disease duration of $9.7 \pm 2.7$ years, 3 males and 3 females). The subject and patient profiles are shown in Table 1.

Clinical diagnosis and pathological confirmation. The criteria of $\mathrm{AD}$ patients are defined by the National Institute on Aging and Reagan Institute Working Group on Diagnostic Criteria for the Neuropathological 
Assessment of Alzheimer's Disease (1997) "high likelihood" and pathological Consortium to Establish a Registry for Alzheimer's Disease (CERAD) neuritic plaque density (Mirra et al., 1991) as well as Braak staging (Braak and Braak, 1991). The details are presented in Table 1. NC subjects were selected based on the absence of a clinical history of dementia and on the results of neuropathological examination.

Cultures of cortical neurons from rapidly autopsied brains. Neurons from the frontal cortex of the $\mathrm{NC}$ and $\mathrm{AD}$ brains (NC and $\mathrm{AD}$ neurons, respectively) were isolated and cultured as described previously (Konishi et al., 2002). Briefly, $\sim 20 \mathrm{~g}$ of brain tissue was taken from the frontal cortex at $0.5-2.5 \mathrm{~h}$ postmortem, digested with papain (Worthington), and processed to increase the purity of the neuronal population. The neurons $\left(1 \times 10^{6} / \mathrm{ml}\right)$ were incubated with tetanus toxin C (TTC) fragments (Boehringer-Ingelheim) followed by an anti-TTC fragment mouse monoclonal antibody (Boehringer-Ingelheim). Microbeads coated with anti-mouse polyclonal antibodies (Miltenyi Biotec) were added for magnetic cell sorting (Miltenyi Biotec). These beads of $50 \mathrm{~nm}$ diameter do not affect cell function or viability and do not need to be removed after sorting, according to the manufacturer's instructions. Approximately $1 \times 10^{6}$ neurons per gram of brain tissue weight were obtained with no significant differences in yield between $\mathrm{NC}$ and $\mathrm{AD}$ neurons. The neurons were cultured in Neurobasal A with B27 (Invitrogen) in the presence or absence of recombinant GDNF, artemin, neurturin, or persephin (R\&D Systems) for further studies.

Immunocytochemistry. The isolated and cultured cortical neurons were immunostained with antibodies against neurons and neurotransmitters as described previously (Konishi et al., 2002). For neuronal identification, antibodies against neurofilament protein (SMI33; Sternberger), microtubule-associated protein-2 (MAP2; Millipore) and neuronal class III $\beta$-tubulin (TUJ1; Covance) were used. Antibodies against glial fibrillary acidic protein (GFAP; DAKO), human leukocyte antigen-DR (LN-3; ICN), von Willebrand factor (vWF; DAKO), and fibronectin (Sigma) were used for non-neuronal identification. Moreover, antibodies that detect neural multipotent progenitors and neural stem cells, anti-NG2 (Millipore) and anti-Musashi (a gift from Dr. H. Okano, Keio University, Tokyo, Japan; Sakakibara and Okano, 1997), respectively, were also used. To detect neurotransmittersynthesizing enzymes, antibodies against phosphate-activated glutaminase (PAG; a gift from Dr. T. Kaneko, Kyoto University, Kyoto, Japan; Kaneko et al., 1987), glutamate decarboxylase (GAD; Millipore), and choline acetyltransferase (ChAT; Millipore) were used. To detect glutamate receptors, antibodies against the NMDA glutamate receptor subtype 1 (GluRN1; Pharmingen, BD Biosciences) and the AMPA-type glutamate receptor types 2 and 4 (GluRA2/4; Pharmingen, BD Biosciences) were used. Secondary antibodies conjugated to Alexa Fluor 488 (Invitrogen) were used for visualization. Sudan Black B (1\%) in 70\% ethanol was used to quench autofluorescence, which is present in large amounts in aged neurons (Schnell et al., 1999).

Cell viability tests and calcium imaging. Three different assays of cell viability were conducted for the cultured neurons using acetoxymethy (AM) ester of calcein (calcein AM) plus ethidium homodimer (EthD-1; LIVE/DEAD Viability/Cytotoxicity test; Invitrogen), SYTO 10 plus DEAD Red (LIVE/DEAD Reduced Biohazard Viability/Cytotoxicity test; Invitrogen), and tetrazolium salts such as 3-(4,5-dimethylthiazol-2-yl)2,5-diphenyltetrazolium bromide (MTT; Invitrogen). For the calcium imaging test, fluo-3 AM (Invitrogen) was used. Methods were briefly described in our previous report (Konishi et al., 2002).

Quantification of neurite extension. For the quantification of neurite extension, as described previously (Chang et al., 1987; Lozano et al., 1995; Savoca et al., 1995), the cortical neurons were plated at a density of $3 \times$ $10^{4}$ cells per well in six-well plates coated with polyethyleneimine (Sigma), cultured in the presence or absence of GDNF at $30 \mathrm{ng} / \mathrm{ml}$, and evaluated as the ratio of total neurite length on day 2 and 7 to that on day 0 . Among different parameters of neurite outgrowth, we measured the length of neurites directly from the base of the soma to the neurite apex, including the length of the cell soma, using the ImageJ program. It is reported that the total neurite length or longest neurite length is a more sensitive measure than neurons with neurite measurement for quantitative assessment of neurite outgrowth in dissociated neuronal cultures
(Mitchell et al., 2007). Neurites were counted only if they had not collided with other test neurites and did not come from a clump of cells (Chang et al., 1987).

Determination of mRNA levels of each GFR subtype by RT-PCR analyses. Total RNA was extracted from the cultured cortical neurons using a reagent for total RNA isolation (Trizol; Invitrogen) and reverse transcribed with MMLV-RT (Invitrogen). The first-strand cDNA was amplified by PCR using AmpliTaq Gold DNA polymerase (Applied Biosystems) and the following specific forward and reverse primers: GFR $\alpha 1$ forward: 5' -GCACAGCTACGGAATGCTCTTCTG-3'; GFR $\alpha 1$ reverse: 5'-GTAGTTGGGGGTCATGACTGTGCCAA-3'; GFR $\alpha 2$ forward: 5'-GAATCCAACTGCAGCTCT-3'; GFR $\alpha 2$ reverse: $5^{\prime}$-AAGCA AGCCTGAAGATGTCC-3'; GFR $\alpha 3$ forward: 5'-GGAACTTGTG CAACAGAGCA-3'; GFR $\alpha 3$ reverse: 5'-ACAGCAAAGGTAGGGTGT GG-3'; GFR $\alpha 4$ forward: 5' -TGCCCTTTGTAGGTTTGGAC-3'; GFR $\alpha 4$ reverse: $5^{\prime}$-TTCTGGGATTCTGGATGGTC- $3^{\prime} ; \beta$-actin forward: $5^{\prime}$ TGGTGGGCATGGGTCAGAAGGATTC- $3^{\prime}$; and $\beta$-actin reverse: $5^{\prime}$ CATGGCTGGGGTGTTGAAGGTCTCA-3'. PCR was performed as follows: $12 \mathrm{~min}$ at $94^{\circ} \mathrm{C}$, followed by 15 and 37 cycles of amplification, respectively, for $\beta$-actin and GFR $\alpha 1-4$, with each cycle consisting of $45 \mathrm{~s}$ at $94^{\circ} \mathrm{C}, 45 \mathrm{~s}$ at the primer-specific annealing temperature, and $1 \mathrm{~min}$ at $72^{\circ} \mathrm{C}$. A final elongation step at $72^{\circ} \mathrm{C}$ for $10 \mathrm{~min}$ completed the reaction. The annealing temperatures were as follows: $60^{\circ} \mathrm{C}$ for GFR $\alpha 1$ and GFR $\alpha 2 ; 58^{\circ} \mathrm{C}$ for GFR $\alpha 3$ and GFR $\alpha 4$; and $56^{\circ} \mathrm{C}$ for $\beta$-actin.

Western blotting. Western blotting was performed as described previously (He et al., 2007). The cultured cortical neurons were lysed in Tris$\mathrm{NaCl}$ buffer containing $0.5 \%$ Triton X-100, $1 \% \beta$-octylglucoside plus protease and phosphatase inhibitors. The total cell lysate was electrophoresed and electroblotted onto nitrocellulose membranes. For the detection of proteins, the membranes were incubated with specific antibodies against GFR $\alpha 1-4$ (R\&D Systems) before the addition of corresponding secondary antibodies conjugated to horseradish peroxidase (Bio-Rad). The enhanced chemiluminescence method (ECL Advance; GE Healthcare) was applied for detection with quantification of the detected bands performed by optical densitometry with FluorChem 8900 (Alpha Innotech). We confirmed the ability of each antibody to detect the correct molecule of the expected size using recombinant protein (data not shown).

Cell transfection. The Adenovirus expression vector kit (Takara Bio) was used for the transduction of target genes into the neurons (Miyake et al., 1996) according to the manufacturer's instructions. Briefly, cDNA for GFR $\alpha 1, \alpha 1$-NCAM, or RET was inserted into the cassette cosmid containing the entire adenovirus serotype 5 genome, except for genes E1 and $\mathrm{E} 3$, and CAG promoter [cytomegalovirus enhancer, chicken $\beta$-actin promoter, and rabbit $\beta$-globin poly (A) signal]. The cosmid has BspT140 I and PacI restriction sites outside both terminal ends of the virus genome. The recombinant adenoviruses expressing GFR $\alpha 1, \alpha 1$-NCAM, or Ret were generated by transfection into HEK293 cells with PacI-digested recombinant cosmid, using FuGENE6 transfection reagent (Roche), and subsequently propagated in HEK293 cells. The quaternary virus seeds were purified by sequential centrifugation in cesium chloride as described previously (Kanegae et al., 1994). The neurons were seeded onto Laminine (BD Bioscience)-coated 12-well plates in Neurobasal A with B27 at a density of $6 \times 10^{3}$ cells per well and infected after $24 \mathrm{~h}$ with purified virus solution for $2 \mathrm{~h}$. Successful transfection was confirmed on day 2 by immunofluorescence using an antibody against GFR $\alpha 1$ (R\&D Systems), $\alpha 1$-NCAM, or RET (Millipore), and also by checking the expression of $\beta$-galactosidase.

To check the $\beta$-galactosidase expression, the cortical neurons were infected with the recombinant adenovirus expressing LacZ (provided in this kit) and stained with X-gal. At a multiplicity of infection (MOI) of $\geq 10, \sim 15-20 \%$ of neurons were positive for $\beta$-galactosidase on day 2 . There were no significant differences in infection efficiencies between $\mathrm{NC}$ and $\mathrm{AD}$ neurons. Infection efficiencies seemed to be more dependent on patient age and postmortem intervals than on disease status. Western blot analysis on day 2 showed that the expression levels of GFR $\alpha 1$ protein in $\mathrm{AD}$ neurons infected with recombinant adenoviruses expressing GFR $\alpha 1$ at an MOI of 50 recovered to the levels corresponding to $\sim 30 \%$ of the levels in uninfected NC neurons, and that the transfection of 

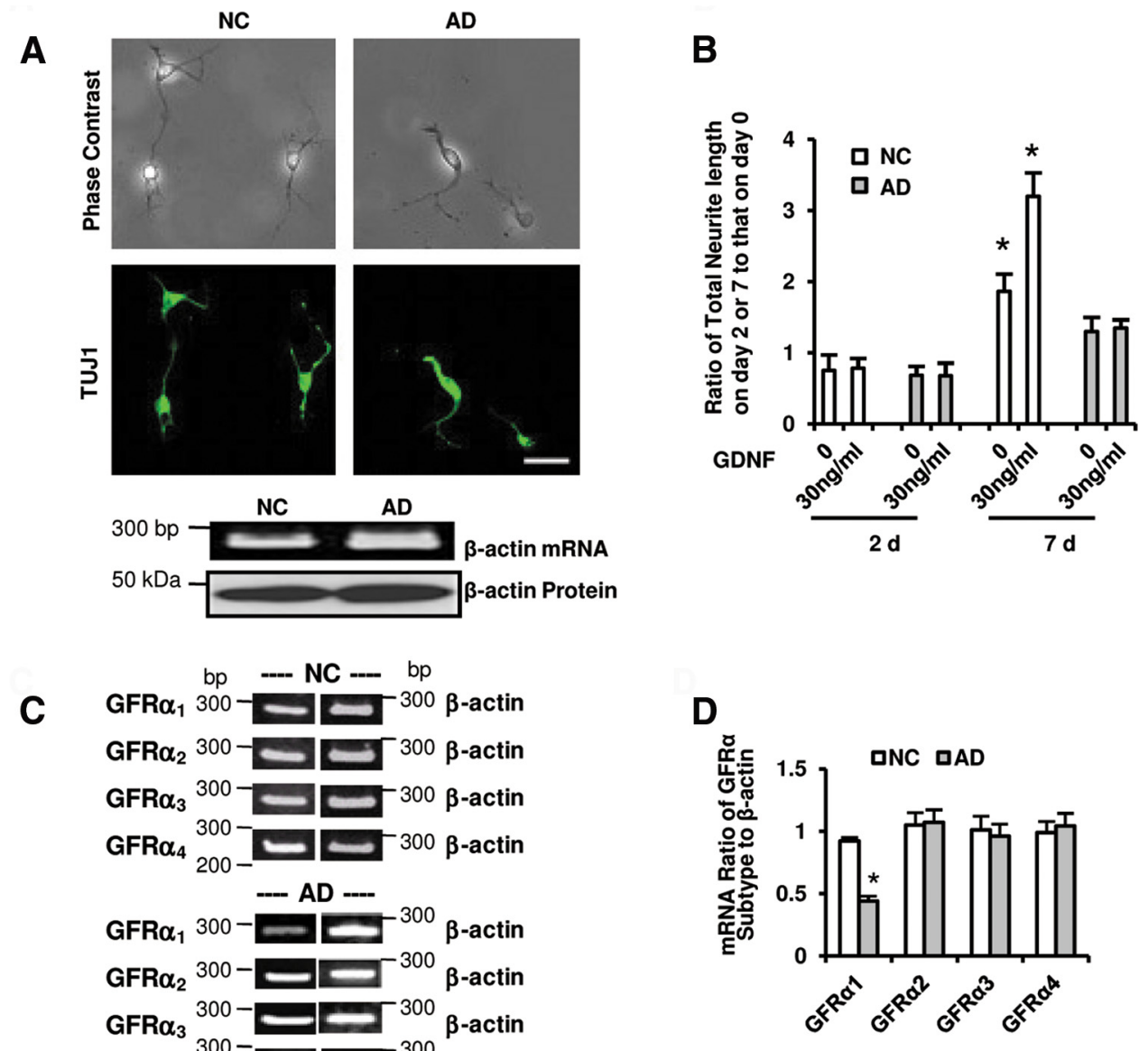

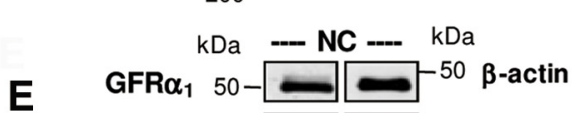 GFR $\alpha_{2} 50-\longrightarrow-50 \beta$-actin $\mathrm{GFR}_{3}$ $\mathrm{GFR}_{4} \boldsymbol{2}_{25-}^{37-}-50$-actin GFR $\alpha_{1}$ GFR $\alpha_{2}{ }_{50} \longrightarrow-50$-actin $\mathrm{GFR}_{3}{ }_{37-}^{50-}{ }^{50} \beta$-actin $\mathrm{GFR}_{4}{ }_{25}{ }^{37-} \longrightarrow{ }^{-50} \beta$-actin

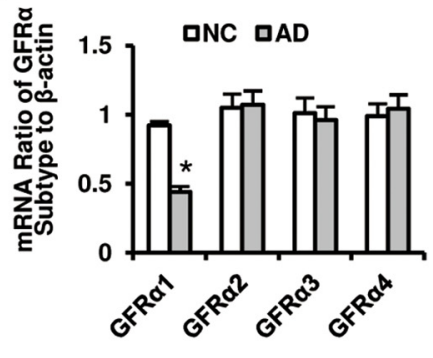

$\mathbf{F}$

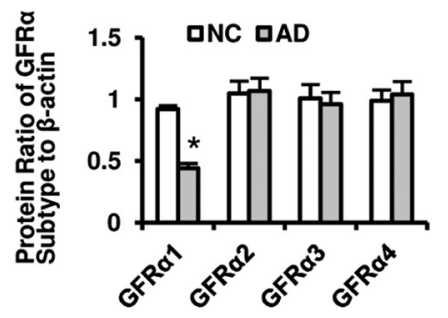

G
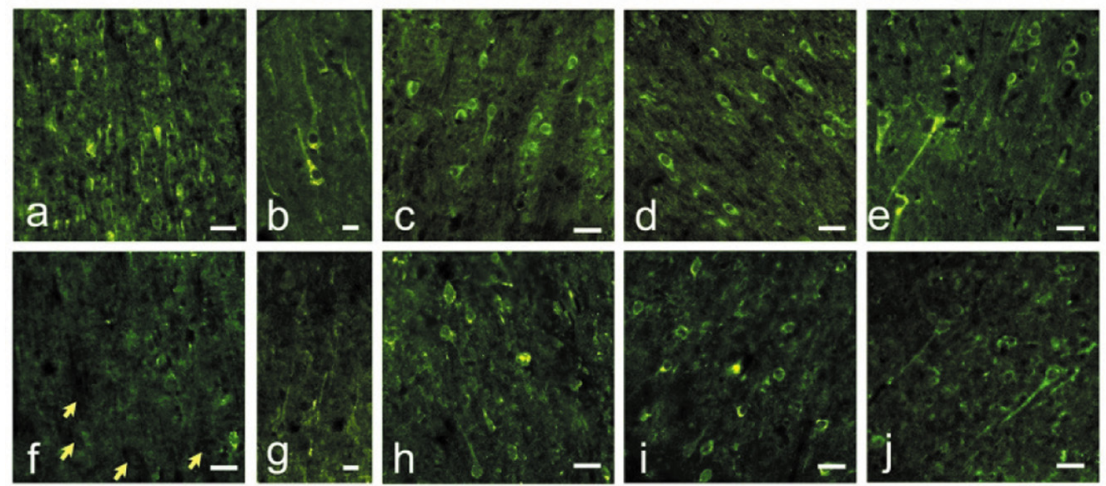

Figure 1. Expression of GFR $\alpha$ in NC and AD neurons. $A$, Cortical neurons isolated from NC and AD brains (NC and AD neurons) were cultured for $7 \mathrm{~d}$ in the presence of $30 \mathrm{ng} / \mathrm{ml}$ GDNF. Representative neurons were verified by phase contrast microscopy and TUJ1 immunostaining. Scale bar, $100 \mu \mathrm{m}$. The $\beta$-actin expression was not different between (Figure legend continues.) 
GFR $\alpha 1$ at an MOI of 50 made the expression levels of GFR $\alpha 1$ protein in NC neurons 1.2-1.3 times higher.

Inhibition of GFR $\alpha 1$ with the antisense oligonucleotide. The following locked nucleic acid-containing oligonucleotides (Wahlestedt et al., 2000) were used for antisense experiments: 5'-GGCACCATGTTCCTA-3' for GFR $\alpha 1$ sense; 5' -TAGGAACATGGTGCC-3' for GFR $\alpha 1$ antisense; 5'TGGTGCGTAGCCATG-3' for $\alpha 1$-NCAM sense; and $5^{\prime}$-CATGGCTACGCACCA- $3^{\prime}$ for $\alpha 1$-NCAM antisense (Wahlestedt et al., 2000; Blaheta et al., 2004). These oligonucleotides were commercially synthesized, purified by HPLC, and transduced into the neurons using an oligofectamine reagent (Invitrogen). Successful transfection was confirmed on days 2 and 5 with Western blot analyses using an antibody against GFR $\alpha 1$ or $\alpha 1$-NCAM.

Evaluation of neuronal survival. Following the transduction of adenoviruses or oligonucleotides, the cortical neurons were cultured in Neurobasal A with B27 in the presence or absence of recombinant GDNF, artemin, neurturin, or persephin for 0,2 , and $5 \mathrm{~d}$; and were subjected to RT-PCR, Western blot, and immunocytochemical analyses. For the cell survival assays, the neurons were cultured for 0,2 , and $7 \mathrm{~d}$. The numbers of surviving neurons were identified by positive staining for NeuN (Millipore) or SMI-33 (Covance) and counted in a blinded manner from triplicate wells of six independent cultures. Neuronal survival rates are shown as the ratio of the percentage of the number of labeled neurons on days 2 and 7 to those on day 0 .

Data analysis. Researchers were always blinded during the experiments, including neuron cultures, and when analyzing raw data from each case. The clinical and pathological diagnoses were unknown until final data analysis. The cases shown in Table 1 are 12 cases of our 30 trials of isolation and in vitro maintenance of neurons from freshly autopsied human brain tissues. For the final data analysis, from these 30 cases we randomly selected six NC subjects and six AD patients who fulfill the clinical and neuropathological criteria for $\mathrm{NC}$ and $\mathrm{AD}$. Results are expressed as the mean $\pm 1 \mathrm{SD}$. All analyses were performed using appropriate software (Excel Statistics 2010; Social Survey Research Information). Differences among three or more groups were evaluated by the Steel-Dwass test following the Kruskal-Wallis test. The level of significance was considered to be $p \leq 0.05$.

\section{Results}

\section{Neuronal and neurotransmitter characterizations}

Our neurons from the frontal cortex of rapidly autopsied brains (six NC and six AD) were characterized with immunocytochemistry for neuron-specific markers, as previously reported (Konishi et al., 2002). Quantitative evaluations of these cells revealed that $76 \pm 5 \%, 70 \pm 4 \%$, and $71 \pm 4 \%$, respectively, were positive for SMI33, MAP2, and TUJ1. In addition, such neuron-rich cultures were found to contain $9.4 \pm 7.3 \%, 8.9 \pm 2.5 \%, 9.5 \pm 7.8 \%$, and $6.8 \pm 1.0 \%$, respectively, of astrocytes, microglia, endothelial

\footnotetext{
$\leftarrow$

(Figure legend continued.) NC and AD neurons at both mRNA and protein levels. $\boldsymbol{B}$, Neurite extension of $N C$ and $A D$ neurons was quantitatively evaluated as the ratio of total neurite length in the presence or absence of GDNF on days 2 and 7 to that on day 0 . We measured the length of neurites directly from the cell base to the neurite apex, including the length of the cell soma. Data were obtained in a blinded manner from triplicate wells of six independent cultures (mean $\pm 1 S D ; n=6 ;{ }^{*} p<0.05$ by the Steel-Dwass test). $\boldsymbol{C}-\boldsymbol{F}$, Representative images of GFR $\alpha$ mRNA $(\boldsymbol{C}, \boldsymbol{D})$ and protein $(\boldsymbol{E}, \boldsymbol{F})$ expressions in NC and AD neurons are shown, and their semiquantitative RT-PCR mRNA (D) and protein $(\boldsymbol{F})$ levels were analyzed by RT-PCR and Western blotting, respectively. The levels of GFR $\alpha$ mRNA and protein were normalized to the corresponding $\beta$-actin. Data were obtained in triplicate from six independent cultures (mean \pm 1 $S D ; n=6 ;{ }^{*} p<0.05$ by the Steel-Dwass test). $G a-j$, Representative images of the immunohistochemistry of GFR $\alpha 1(\boldsymbol{a}, \boldsymbol{b}, \boldsymbol{f}, \boldsymbol{g}), \operatorname{GFR} \alpha 2(\boldsymbol{c}, \boldsymbol{h}), \operatorname{GFR} \alpha 3(\boldsymbol{d}, \boldsymbol{i})$, and GFR $\alpha 4(\boldsymbol{e}, \boldsymbol{j})$ in the temporal cortex from the NC $(\boldsymbol{a}-\boldsymbol{e})$ and AD $(\boldsymbol{f}-\boldsymbol{j})$ brain. Tissue sections were incubated with specific antibodies against GFR $\alpha 1-4$ (R\&D Systems) before the addition of corresponding secondary biotinylated antibodies (Vector Laboratories), followed by visualization with streptavidin-Alexa Fluor 488 (Invitrogen). Yellow arrows depict unstained neurons. Scale bars: $\boldsymbol{b}, \boldsymbol{g}, 50 \mu \mathrm{m} ; \boldsymbol{a}, \boldsymbol{c}-\boldsymbol{f}, \boldsymbol{h}-\boldsymbol{j}, 100 \mu \mathrm{m}$.
}

cells, and fibroblasts by using specific antibodies against each cell type of marker, including GFAP, LN-3, vWF, and fibronectin. The percentage of cells immunoreactive to NG2 was $3.7 \pm 3.6 \%$. The neuron-rich cultures lacked immunoreactivity for the Musashi. These types of cells showed no changes in percentage throughout the culture periods, and there were no significant differences in the percentage of cells labeled with any antibody mentioned above between $\mathrm{NC}$ and $\mathrm{AD}$ neurons, suggesting that our primary cells were not differentiated from immature progenitors or stem cells in cultures. Furthermore, to determine neurotransmitter phenotypes, these neurons were evaluated for synthesizing enzymes of glutamate, GABA, and acetylcholine (images not shown), showing that PAG-, GAD-, and ChATpositive neurons comprised $61 \pm 10 \%, 49 \pm 11 \%$, and $8.1 \pm$ $1.6 \%$, which are presumed to be glutamatergic, GABAergic, and cholinergic neurons, respectively. These proportions of PAG-, GAD-, and ChAT-positive neurons in our cultures are almost consistent with the estimated $75 \%, 35 \%$, and $\sim 10 \%$ prevalence of glutamatergic, GABAergic, and cholinergic neurons, respectively, in the intact human or primate adult neocortex (Hendry et al., 1987; Akiyama et al., 1990; Kasashima et al., 1999). The percentage of glutamatergic, GABAergic, and cholinergic neurons isolated from the autopsied $\mathrm{AD}$ brains was not different from that isolated from the autopsied NC brains, suggesting that there is no phenotypic preference for cell loss in AD neuron culture processes, compared with NC neuron culture processes, as judged from data on neuronal and neurotransmitter markers.

\section{Biochemical evaluation of neuronal activity}

Three different assays of cell viability were performed for our neurons ( six NC subjects and six AD patients) after $7 \mathrm{~d}$ in vitro in the presence of GDNF. The LIVE/DEAD Viability/Cytotoxicity test uses 30 min incubation of cells with calcein AM and EthD-1. Green fluorescence indicates living cells, while red fluorescence indicates dead cells. In the presence of esterase activity, calcein AM is metabolized to calcein, producing green fluorescence, according to the manufacturer's instructions. NC neurons consisted of $75 \pm 12 \%$ living cells and $18 \pm 6 \%$ dead cells, whereas the $\mathrm{AD}$ neurons consisted of $35 \pm 9 \%$ living cells and $61 \pm 11 \%$ dead cells. The LIVE/DEAD Reduced Biohazard Viability/Cytotoxicity test uses 15 min incubation of cells with SYTO10 and DEAD Red. With the staining method recommended by the manufacturer's instructions, living cells appear fluorescent green and dead cells fluoresce red. NC neurons consisted of $65 \pm 10 \%$ living cells and $28 \pm 5 \%$ dead cells, whereas AD neurons consisted of $39 \pm 12 \%$ living cells and $66 \pm 13 \%$ dead cells. Tetrazolium salts are water-soluble colorless compounds that form highly colored water-insoluble formazans after reduction by the respective specific components of the electron transport chain in mitochondria of only living cells (Abe and Saito, 1998). In $65 \pm$ $11 \%$ of $\mathrm{NC}$ neurons and $37 \pm 10 \%$ of $\mathrm{AD}$ neurons, purple formazan granules were recognized when 3-(4,5-dimethylthiazol2-yl)-2,5-diphenyltetrazolium bromide was used as tetrazolium salts, indicating that they are living cells.

In the calcium imaging test, the neurons after $7 \mathrm{~d}$ in vitro (six NC subjects and six AD patients) were loaded with fluo-3 AM and exposed to $50-100 \mathrm{mmol} / \mathrm{L} \mathrm{KCl}$ to induce calcium influx. We found that $58 \pm 12 \%$ NC neurons and $24 \pm 9 \%$ AD neurons exhibited increments in calcium influx. In addition, cells loaded with fluo-3 AM were exposed to glutamate at 100-500 $\mu \mathrm{mol} / \mathrm{L}$, showing that $55 \pm 9 \%$ of $\mathrm{NC}$ neurons and $20 \pm 7 \%$ of $\mathrm{AD}$ neurons exhibited increases in calcium influx. 


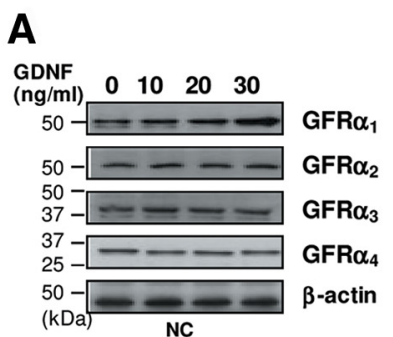

B
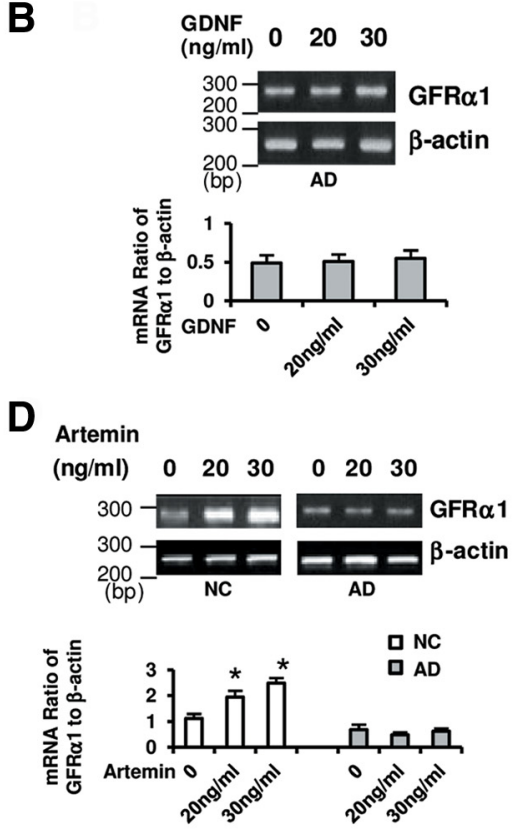

$\mathbf{F}$
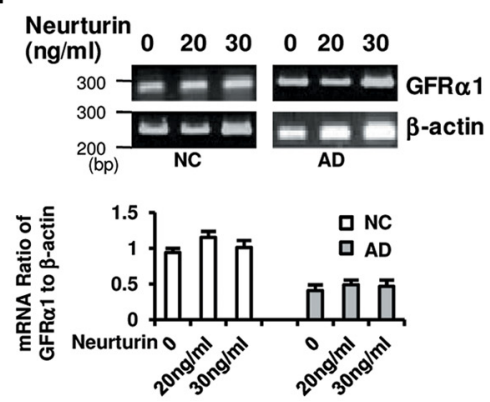

H

| ASO

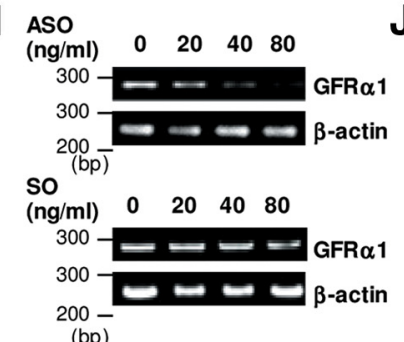

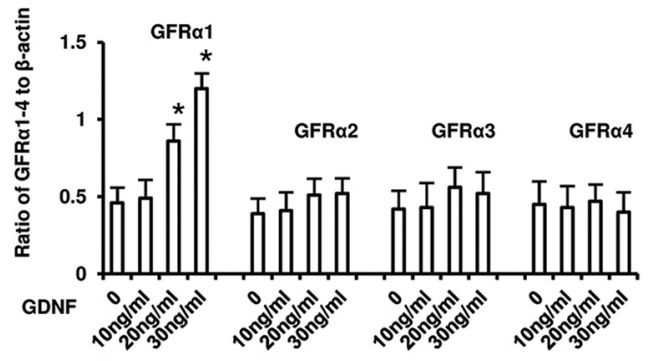

C
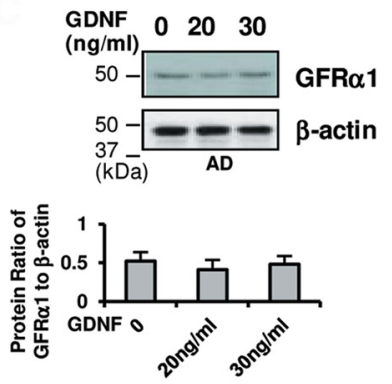

E
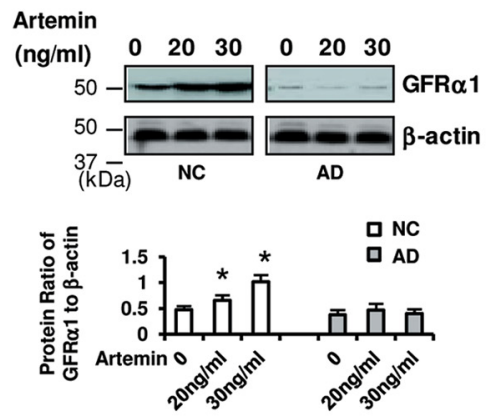

G

$\begin{array}{lllllll}\text { Neurturin } & 0 & 20 & 30 & 0 & 20 & 30\end{array}$

(ng/ml)
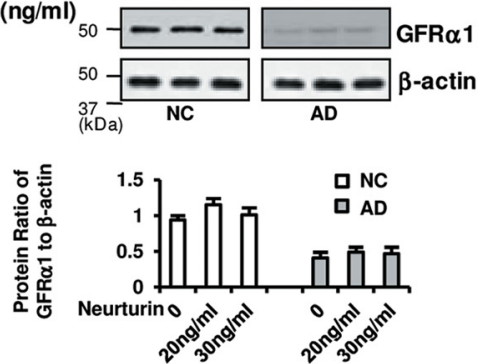

J ASO

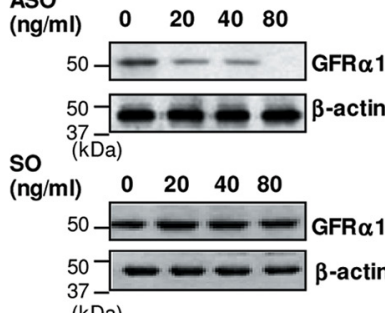

Figure 2. GDNF enhances the expression of GFR $\alpha 1$ in NC but not AD neurons. A, Representative images of GFR $\alpha$ expression in NC neurons are shown, and semiquantitative analyses of the expression levels are presented. GFR $\alpha 1$ expressions, but not GFR $\alpha 2$, GFR $\alpha 3$, or GFR $\alpha 4$ expressions, were upregulated in response to exogenous GDNF in a dose-dependent manner in NC neurons. $\boldsymbol{B}, \boldsymbol{C}$, Representative images of GFR $\alpha 1 \mathrm{mRNA}(\boldsymbol{B})$ and protein $(\boldsymbol{C})$ expressions in $A D$ neurons are shown. The levels of GFR $\alpha 1 \mathrm{mRNA}(\boldsymbol{B})$ or protein $(\boldsymbol{C})$ expressions were not significantly elevated in the presence of GDNF in AD neurons. $\boldsymbol{D}-\boldsymbol{G}$, Representative images of GFR $\alpha 1 \mathrm{mRNA}(\boldsymbol{D}, \boldsymbol{F})$ and protein $(\boldsymbol{E}, \boldsymbol{G})$ expressions in NC and AD neurons are shown. The levels of GFR $\alpha 1 \mathrm{mRNA}(\boldsymbol{D})$ and protein $(\boldsymbol{E})$ were upregulated in NC but not in $A D$ neurons in the presence of artemin. In contrast, there was no significant elevation of $\mathrm{mRNA}(\boldsymbol{F})$ or protein $(\boldsymbol{G})$ levels in either NC or AD neurons in the presence of neurturin. All of the results of GFR $\alpha$ mRNA and protein levels were normalized to the corresponding $\beta$-actin. $A-G$, Data were obtained in triplicate from six independent cultures (mean \pm 1 SD; $n=6 ;{ }^{*} p<0.05$ by the Steel-Dwass test). $\boldsymbol{H}$, Photoimages show, in the presence of GDNF for 5 d, downregulation of GFR $\alpha 1$ protein expression in NC neurons with the introduction of GFR $\alpha 1$ ASOs but not with the introduction of GFR $\alpha 150$ s. $I, J$, Similar to the finding in the presence of GDNF, in the presence of artemin for $5 \mathrm{~d}$ GFR $\alpha 1 \mathrm{mRNA}(\boldsymbol{I})$ and protein $(\boldsymbol{I})$ expression were downregulated in NC neurons with the introduction of GFR $\alpha 1$ ASOs, but not with introduction of GFR $\alpha 1$ SOs. 


\section{GFR $\alpha 1$ expression is downregulated in $\mathrm{AD}$ neurons}

In the presence of GDNF, there was no obvious axonal growth of $\mathrm{AD}$ neurons, while NC neurons were able to grow neurites (Fig. $1 A)$; therefore, neurite extension was quantitatively evaluated under a phase-contrast microscope (Fig. $1 B$ ). These observations led us to consider further challenging experiments to determine whether $\mathrm{NC}$ and $\mathrm{AD}$ neurons could express GDNF receptors differently, since GDNF functions through its receptor subtypes, GFR $\alpha 1-4$ (Sariola and Saarma, 2003).

With semiquantitative RT-PCR analysis, all four GFR $\alpha$ subtypes, GFR $\alpha 1-4$, were demonstrated to be expressed equally in NC neurons (Fig. 1C,D). Surprisingly, GFR $\alpha 1$ expression, but not GFR $\alpha 2$, GFR $\alpha 3$, or GFR $\alpha 4$ expression, was significantly reduced in $\mathrm{AD}$ neurons compared with NC neurons (Fig. $1 C, D$ ). We looked at each subtype individually using Western blotting to see whether the protein levels corresponded to their mRNA levels (Fig. $1 E, F$ ). In NC neurons, GFR $\alpha 1-4$ were equally expressed at moderate levels, whereas the expression of GFR $\alpha 1$, but not the other three subtypes, was significantly reduced in $\mathrm{AD}$ neurons (Fig. $1 E, F$ ). This selective reduction of GFR $\alpha 1$ in AD neurons in vitro was confirmed in noncultured postmortem brain tissues from five NC subjects $(84.0 \pm 9.6$ years old, three males and two females) and five $\mathrm{AD}$ patients $(79.4 \pm 6.9$ years old, three males and two females; Fig. $1 G$ ), which were different from the six NC subjects and six AD patients used in the present in vitro culture study.

\section{GDNF enhances the expression of GFR $\alpha 1$ in NC but not in}

\section{AD neurons}

To examine whether GDNF regulates the expression of its own receptor subtype in neurons, GDNF was added daily to cultured neurons. The neurons were then harvested on days 2 and 5 to conduct Western blot analysis to determine the protein levels of GFR $\alpha 1-4$. In NC neurons, the expression of GFR $\alpha 1$ was selectively enhanced in a dose-dependent manner by GDNF treatment for $5 \mathrm{~d}$, but no significant change in the expression of the other three GFR $\alpha$ subtypes was observed (Fig. $2 A$ ). In $\mathrm{AD}$ neurons, however, there were no significant changes in the mRNA or protein expression of any of the four GFR $\alpha$ subtypes with GDNF treatment (Fig. $2 B, C$; data for GFR $\alpha 2$, GFR $\alpha 3$, or GFR $\alpha 4$ are not shown). The time course of the regulation of GFR $\alpha 1$ expression by GDNF in NC and AD neurons ( $n=6$ for each) was examined, as follows: increases in GFR $\alpha 1 \mathrm{mRNA}$ and protein levels in NC neurons with GDNF treatment for 5 and $7 \mathrm{~d}$ were significant compared with those in $\mathrm{AD}$ neurons, although there was no significant change between $\mathrm{NC}$ and $\mathrm{AD}$ neurons in the expression of GFR $\alpha 1$ with $2 \mathrm{~d}$ treatment (data not shown).

A new GDNF member, artemin (Baloh et al., 1998), shares GFR $\alpha 1$ with GDNF (Sariola and Saarma, 2003). To examine whether artemin regulates the expression of GFR $\alpha 1$ similarly to GDNF, it was added daily to NC and AD neurons for 2 and $5 \mathrm{~d}$. All experiments were performed exactly as those for GDNF, except that artemin was used instead of GDNF. GFR $\alpha 1$ mRNA (Fig. 2D) and protein (Fig. 2E) expressions were significantly enhanced in NC neurons by artemin treatment, although GFR $\alpha 2$, GFR $\alpha 3$, or GFR $\alpha 4$ expressions were not. In contrast, no change was seen in $\mathrm{AD}$ neurons treated with artemin (Fig. 2D,E).

Neurturin is known to activate GFR $\alpha 1$ and GFR $\alpha 2$ receptors (Rosenthal, 1999). To examine whether neurturin affects GFR $\alpha 1$ expression in both NC and AD neurons, it was added daily to cultured neurons for 2 and $5 \mathrm{~d}$. RT-PCR and Western blot analyses were used for the detection of GFR $\alpha 1$ mRNA and protein, respectively. No significant changes were seen in GFR $\alpha 1$ mRNA
A

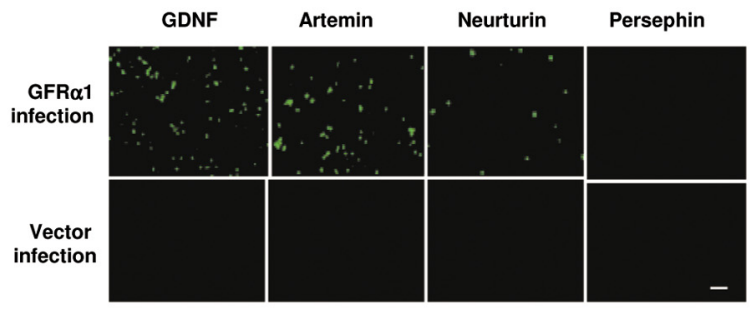

B

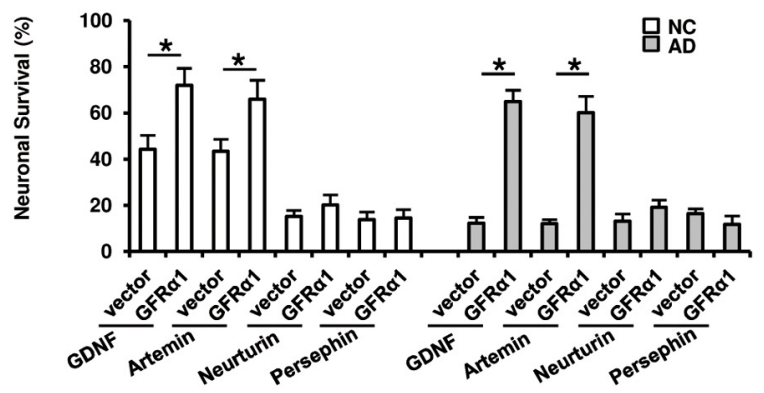

C

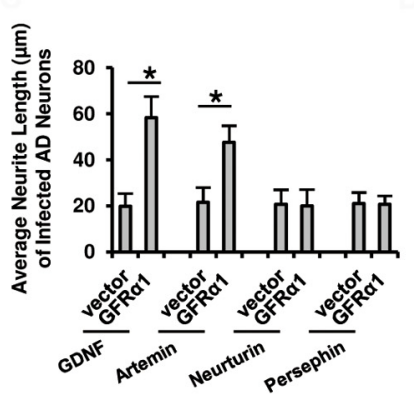

D

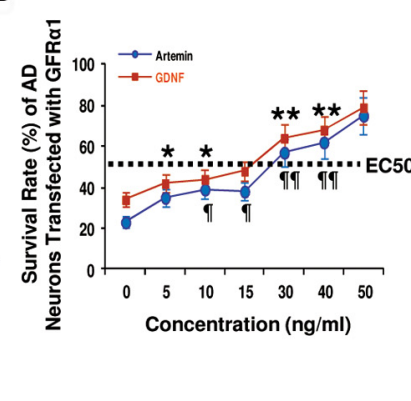

Figure 3. GDNF and artemin promote cortical neuronal survival. $A, A D$ neurons were cultured in the presence of GDNF, artemin, neurturin, or persephin for $7 \mathrm{~d}$. During cultures, $A D$ neurons were infected with GFR $\alpha 1$. The survival of neurons was verified by the antibody against NeuN. With GFR $\alpha 1$ infection, the number of surviving neurons was increased in the presence of GDNF or artemin, but not with treatment with neurturin or persephin. Scale bar, $200 \mu \mathrm{m}$. B, NC and $A D$ neurons were infected with GFR $\alpha 1$ or empty vector in the presence of GDNF, artemin, neurturin, or persephin for $7 \mathrm{~d}$. GDNF and artemin significantly supported cell survival in NC and $A D$ neurons infected with GFR $\alpha 1$, compared with those infected with the corresponding empty vectors. ${ }^{*} p<0.05$ by the Steel-Dwass test. Note that GDNF and artemin supported the survival of $A D$ neurons only when the cells were infected with GFR $\alpha 1$. In contrast, neurturin or persephin did not play a role. $C, A D$ neurons were infected with GFR $\alpha 1$ or empty vector for $7 \mathrm{~d}$. The neurite outgrowth of $A D$ neurons infected with GFR $\alpha 1$ was significantly promoted in the presence of GDNF or artemin compared with those infected with the corresponding empty vector $\left({ }^{*} p<\right.$ 0.05 by the Steel-Dwass test); however, neurite extension was not significantly increased in AD neurons in the presence of neurturin or persephin even when GFR $\alpha 1$ was infected. The neurites from each neuron in designated fields (minimum of 150 cells of two to four wells in four-well dishes) were counted using photoimages taken with a phase-contrast microscope. The experiments were independently repeated six times. $\boldsymbol{D}$, Dose response of the survival-promoting effect of GDNF and artemin on AD neurons infected with GFR $\alpha 1$. The effect of GDNF and artemin was dose dependent. $p<0.05$, in comparison with data at two different concentrations of GDNF or artemin, except for comparison between the data with GDNF at 5 and $10\left(^{*}\right)$ and 30 and $40\left({ }^{* *}\right)$, and artemin at 10 and 15 (१) and 30 and 40 (११) ng/ml (Steel-Dwass test). $\boldsymbol{B}$-D, The data were obtained in a blinded manner from triplicate wells of six independent cultures $(n=$ $6 ;$ mean $\pm 1 S D)$.

or protein expression after incubation with neurturin in $\mathrm{NC}$ or $\mathrm{AD}$ neurons (Fig. $2 F, G$ ). In addition, persephin did not upregulate GFR $\alpha 1$ expression in NC or AD neurons ( $n=6$ for each; data not shown); therefore, GFR $\alpha 1$ expression is independent of neurturin or persephin in cortical neurons; that is, neurturin or 
A

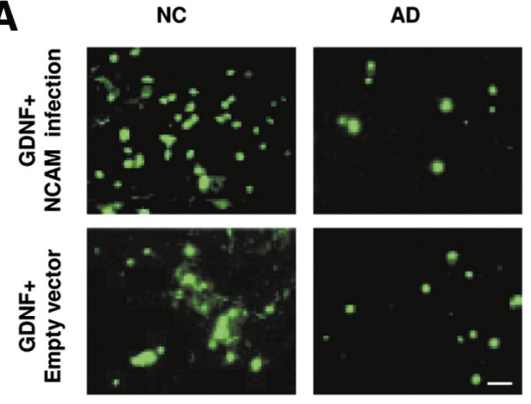

B

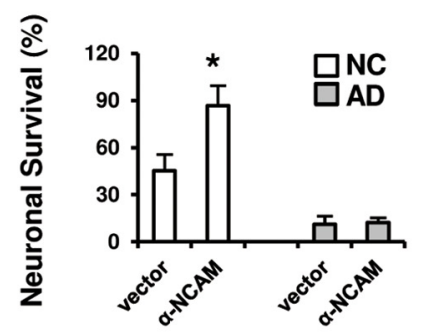

C

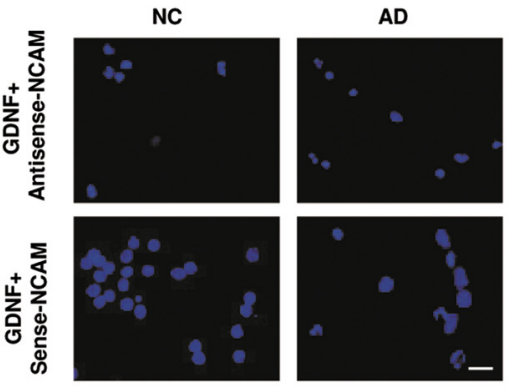

D

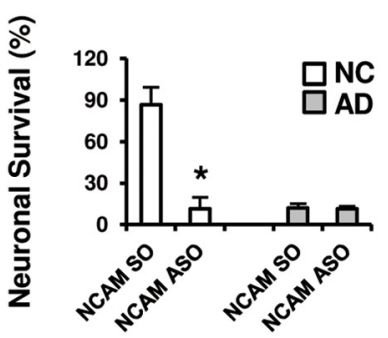

E

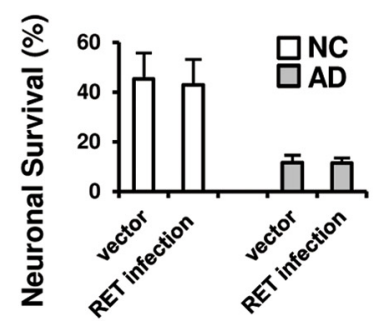

Figure 4. $\quad \alpha 1$-NCAM contributes to the regulation of NC neurons, but not AD neurons, by GDNF. A, Neurofilament protein (SMI-33) immunofluorescence images show that, with $\alpha 1$ NCAM infection, the survival of NC neurons was increased, but that of AD neurons was not. Scale bar, $100 \mu \mathrm{m}$. $B$, In the presence of GDNF, NC and AD neurons were grown and infected with either $\alpha 1$-NCAM or empty vector. Neurons positive for SMI-33 were calculated on day 7 . The number of surviving neurons in the presence of GDNF was significantly increased in NC neurons infected with $\alpha 1$-NCAM ( ${ }^{*} p<0.05$ by the Steel-Dwass test), but not in AD neurons infected with $\alpha 1$-NCAM. C, Immunofluorescence images of SMI-33 show the effect of ASOs and SOs of $\alpha 1$-NCAM. Scale bar, $100 \mu \mathrm{m}$. D, NC and AD neurons were transfected with $\alpha 1$-NCAM ASOs or persephin does not upregulate GFR $\alpha 1$ expression in $\mathrm{NC}$ or $\mathrm{AD}$ neurons.

To further verify the effect of GDNF on its specific cell-surface receptor, GFR $\alpha 1$, we used antisense oligonucleotides (ASOs) against GFR $\alpha 1$ in the presence of GDNF for $5 \mathrm{~d}$. GFR $\alpha 1$ protein expression was knocked down in NC neurons. In the presence of GDNF, the introduction of GFR $\alpha 1$ ASOs inhibited GFR $\alpha 1$ protein expression in NC neurons in a dose-dependent manner (Fig. $2 \mathrm{H}$ ). The introduction of sense oligonucleotides (SOs) for GFR $\alpha 1$ did not inhibit GFR $\alpha 1$ expression in NC neurons (Fig. $2 H)$. Similarly, to verify the specific regulatory effects of artemin on its specific cell-surface receptor, GFR $\alpha 1$, NC neurons were transfected with the ASO against GFR $\alpha 1$ for $5 \mathrm{~d}$. In the presence of artemin, GFR $\alpha 1$ ASOs inhibited GFR $\alpha 1$ mRNA (Fig. 2I) and protein (Fig. $2 J$ ) expression in NC neurons in a dose-dependent manner, while the GFR $\alpha 1$ SOs did not have any effect on GFR $\alpha 1$ expression in NC neurons (Fig. 2I,J). The introduction of either ASOs against GFR $\alpha 2$, GFR $\alpha 3$ or GFR $\alpha 4$, or SOs for them had no effect on GFR $\alpha 1$ expression in NC neurons under treatment with GDNF or artemin. Also, levels of mRNA and protein of $\beta$-actin showed no alteration even if an ASO against GFR $\alpha 1$ was added. These results indicated that these oligonucleotides were not toxic to neurons.

\section{Survival and neurite outgrowth improve in $\mathrm{AD}$ neurons transfected with GFR $\alpha 1$}

The present data suggest that artemin may act like GDNF to influence neuronal survival through GFR $\alpha 1$ expression. NC and $\mathrm{AD}$ neurons were cultured for $7 \mathrm{~d}$, and the ability of artemin to support neuronal survival was compared with that of GDNF, neurturin, and persephin. The surviving neurons were identified by immunocytochemistry for $\mathrm{NeuN}$ (Fig. $3 A$ ). The survival rates of NC and AD neurons infected with GFR $\alpha 1$ under treatment with artemin were $66 \pm 8 \%$ and $60 \pm 7 \%$, respectively, and those of NC and AD neurons infected with GFR $\alpha 1$ under treatment with GDNF were $72 \pm 7 \%$ and $65 \pm 5 \%$, respectively (Fig. $3 B$ ). Thus, treatment with artemin or GDNF resulted in much higher survival rates of $\mathrm{NC}$ and $\mathrm{AD}$ neurons infected with GFR $\alpha 1$ than treatment with neurturin or persephin. With artemin or GDNF, the survival rates of NC neurons not infected with GFR $\alpha 1$ (infected with empty vector) increased to some extent ( $43 \pm 5 \%$ and $44 \pm 6 \%$, respectively), but those of $\mathrm{AD}$ neurons not infected with GFR $\alpha 1$ did not (Fig. 3B); that is, GDNF and artemin support the survival of AD neurons only when the cells are infected with GFR $\alpha 1$. Interestingly, in NC neurons, GDNF and artemin supported survival, even without the introduction of GFR $\alpha 1$; this was possibly due to the original expression of GFR $\alpha 1$ in NC neurons. Neither neurturin nor persephin supported the survival of NC or AD neurons to the same extent as GDNF and artemin, even when GFR $\alpha 1$ was overexpressed (Fig. 3B). The length of neurite outgrowth in $\mathrm{AD}$ neurons was significantly shorter than that of NC neurons; that is, in the presence of GDNF, the neurites of NC neurons were significantly extended; however, the result was not observed in $\mathrm{AD}$ neurons (Fig. $1 A, B$ ). Here we showed

$\leftarrow$

SOs, combined with the presence of GDNF for $7 \mathrm{~d}$. $\alpha 1$-NCAM ASOs significantly decreased the survival of NC neurons. Due to the low survival rate of AD neurons, transfection with $\alpha 1-N C A M$ ASOs had little effect on survival. $\boldsymbol{E}$, In the presence of GDNF, NC and AD neurons were grown and infected with either RET or empty vector. No significant differences were seen between infections of empty vector and RET in NC neurons as well as in AD neurons. $\boldsymbol{B}, \boldsymbol{D}, \boldsymbol{E}$, Data were obtained in a blinded manner from triplicate wells of six independent cultures ( $n=6$; mean \pm 1SD). 

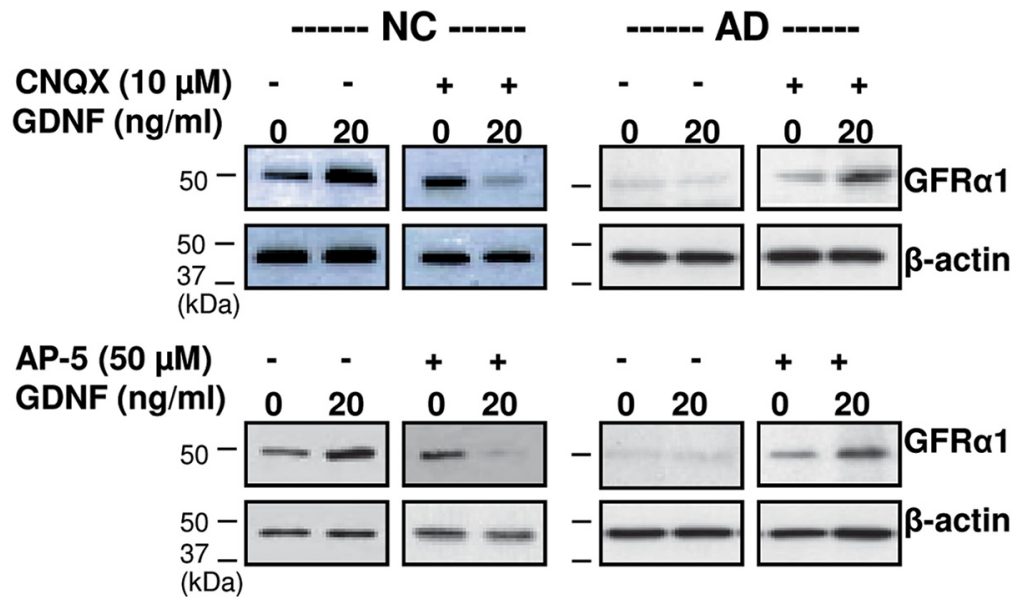

Figure 5. Blockage of glutamate receptors regulates levels of GFR $\alpha 1$ expression in cortical neurons. Our neurons (six NC subjects and six AD patients) were incubated with GDNF $(20 \mathrm{ng} / \mathrm{ml})$ in the absence or presence of either the AMPA receptor blocker CNQX (10 $\mu \mathrm{m})$ or the NMDA receptor blocker AP-5 $(50 \mu \mathrm{m})$ for $7 \mathrm{~d}$. CNQX and AP-5 completely abolished the GDNF-enhanced GFR $\alpha 1$ protein expression in NC neurons (left panels). On the other hand, in AD neurons, CNQX and AP- 5 greatly enhanced GFR $\alpha 1$ protein expression under GDNF treatment (right panels), whereas, without CNQX or AP-5, GFR $\alpha 1$ expression was neither induced nor enhanced by GDNF administration alone.

that the survival of $\mathrm{AD}$ neurons was enhanced with GFR $\alpha 1$ infection. Whether neurite outgrowth could also be significantly promoted by GFR $\alpha 1$ infection is still unclear; therefore, we introduced GFR $\alpha 1$ or empty vector into isolated $\mathrm{AD}$ neurons. Neurite extension was evaluated as the average neurite length. For this, $\mathrm{AD}$ neurons were cultured for $7 \mathrm{~d}$ and the average neurite length was measured in a blinded manner from triplicate wells of six independent cultures. We found that, under treatment with GDNF, the average neurite length of $\mathrm{AD}$ neurons infected with GFR $\alpha 1$ was significantly increased by twofold ( $58 \pm 9$ $\mu \mathrm{m})$ compared with that of $\mathrm{AD}$ neurons infected with empty vector $(20 \pm 6 \mu \mathrm{m})$. Similarly, under treatment with artemin, the average neurite length of AD neurons infected with GFR $\alpha 1$ was increased to $48 \pm 8 \mu \mathrm{m}$ compared with empty vector-infected AD neurons (Fig. 3C); however, enhanced neurite outgrowth was not observed in $\mathrm{AD}$ neurons infected with GFR $\alpha 1$ in the presence of neurturin or persephin (Fig. 3C).

Dose-response analysis of the survival-promoting effect of artemin and GDNF on AD neurons infected with GFR $\alpha 1$ revealed an $\mathrm{EC}_{50}$ of 15-29 $\mathrm{ng} / \mathrm{ml}$ (Fig. 3D).

\section{$\alpha 1-N C A M$ contributes to the regulation of NC but not AD neurons by GDNF}

To examine whether GDNF, via its interaction with $\alpha 1$-NCAM, an alternative signaling receptor for GDNF (Paratcha et al., 2003; Iwase et al., 2005), could enhance neuronal survival, NC and AD neurons were grown in the presence or absence of GDNF for $7 \mathrm{~d}$, accompanying the infection of $\alpha 1$-NCAM (Fig. $4 A, B$ ). The surviving neurons were identified by immunocytochemistry for SMI-33 (Fig. 4A). $\alpha 1$-NCAM infection induced an $\sim 1.5$-fold increase in the survival rate of NC neurons in the presence of GDNF for $7 \mathrm{~d}$ (Fig. 4B), similar to the finding that GFR $\alpha 1$ infection resulted in an $\sim 1$.5-fold increase in NC neurons (Fig. $3 B$ ). In contrast, the survival rates of $\mathrm{AD}$ neurons were barely influenced by $\alpha 1$-NCAM infection, even under treatment with GDNF (Fig. 4B).

Next, NC and AD neurons were transfected with $\alpha 1$-NCAM ASOs or SOs in the presence of GDNF for $7 \mathrm{~d}$. Immunofluorescence images for SMI-33 showed the effect of $\alpha 1$-NCAM ASOs and SOs (Fig. 4C). $\alpha 1$-NCAM ASOs significantly decreased the survival of $\mathrm{NC}$ neurons (Fig. 4D). The introduction of $\alpha 1$-NCAM ASOs had little effect on the low survival rate of AD neurons (Fig. 4D). In addition, no significant changes were observed in the survival of either $\mathrm{NC}$ or $\mathrm{AD}$ neurons in the presence of GDNF after RET infection (Fig. 4E). Even when RET was introduced into AD neurons in the presence of GDNF (Fig. $4 E$ ), the survival rate of $\mathrm{AD}$ neurons was comparable to that with $\alpha 1$-NCAM infection (Fig. $4 B)$. Thus, the introduction of GFR $\alpha 1$ but not $\alpha 1$-NCAM or RET into AD neurons can restore the ability of GDNF to rescue AD neurons.

\section{Blockage of glutamate receptors regulates levels of GFR $\alpha 1$ expression in cortical neurons}

It is generally accepted that glutamate receptors are important for the expression and function of NTFs and their receptors (Levine et al., 1998; Nicole et al., 2001). To understand whether glutamate receptors are involved in GFR $\alpha 1$ regulation by GDNF, neurons were incubated with $20 \mathrm{ng} / \mathrm{ml}$ GDNF in the presence of either the AMPA receptor blocker CNQX $(10 \mu \mathrm{M})$ or the NMDA receptor blocker AP-5 (50 $\mu \mathrm{M}$; Sigma-Aldrich) for $7 \mathrm{~d}$. In NC neurons, CNQX and AP-5 were found to completely abolish GDNF-enhanced GFR $\alpha 1$ protein expression (Fig. 5, left column). In AD neurons, on the other hand, CNQX and AP-5 significantly enhanced GFR $\alpha 1$ protein expression in the presence of GDNF (Fig. 5, right column). Therefore, it appears that glutamate receptors are involved in the regulation of GFR $\alpha 1$ by GDNF. In NC neurons, the presence of glutamate receptors is necessary for GDNF-linked GFR $\alpha 1$ expression, while in AD neurons the absence of glutamate receptors is absolutely required for GFR $\alpha 1$ expression by GDNF stimulation. Without treatment with glutamate receptor antagonists in AD neurons, GFR $\alpha 1$ expression was neither induced nor enhanced by GDNF administration alone (Fig. 5, right column). This finding also suggests that, to prevent or rescue neuronal death/damage in AD brains, the treatment of glutamate receptor antagonists alone may not be sufficient. The combination of NTFs such as GDNF with glutamate receptor antagonists may be necessary to rescue neuronal damage in $\mathrm{AD}$ neurodegeneration. The administration of GDNF alone is also unlikely to show some beneficial effects on damaged AD neurons. For healthy elderly NC neurons, on the other hand, the combination of GDNF with glutamate receptor antagonists may show opposite adverse or deteriorating effects, although treatment with glutamate receptor antagonists alone may be somewhat effective.

\section{Discussion}

GDNF is a potent NTF for a variety of neuronal populations (Walton, 1999). Our report is the first to show a key deficit in GDNF-GFR $\alpha 1$ signaling in human AD neurons. Here we demonstrated a significant decrease in the GFR $\alpha 1$ levels in AD neurons in vitro. This was confirmed in noncultured postmortem brain tissues from AD patients; that is, the selective reduction of GFR $\alpha 1$ expression was also detectable in cortical neurons in AD brain tissues, but not in NC brain tissues. This indicates that the 
decreased expression of GFR $\alpha 1$ is a manifestation of AD pathology, but is not a consequence of in vitro culturing processes. The introduction of GFR $\alpha 1$, but not $\alpha 1$-NCAM or RET, into AD neurons restored the enhancement of cell survival by GDNF. Although $\alpha 1$-NCAM is required as an essential component of GFR $\alpha 1$-linked signal cascades for neuronal survival (Paratcha et al., 2003), it is likely that a deficit of GFR $\alpha 1$ is one of the key factors for cell death in AD neurons. Thus, for effective GDNFmediated AD therapy, it is essential to induce or enhance GFR $\alpha 1$ expression. We will further address the selectivity of GFR $\alpha 1$, and why GFR $\alpha 2$, GFR $\alpha 3$, and GFR $\alpha 4$ are not changed, using GFR $\alpha$ subtype knock-out mice.

The time course of GFR $\alpha 1$ expression in $\mathrm{NC}$ and $\mathrm{AD}$ neurons can exclude the possibility of decreased turnover of GFR $\alpha 1$ over time in NC neuron cultures and/or enhanced turnover of GFR $\alpha 1$ over time in $\mathrm{AD}$ neuron cultures. We found that, between NC and $\mathrm{AD}$ neurons, there were no significant changes in the expression of GFR $\alpha 1$ with $2 \mathrm{~d}$ treatment with GDNF, but that, with 5 and $7 \mathrm{~d}$ GDNF treatment, the mRNA and protein levels of GFR $\alpha 1$ subtype in $\mathrm{AD}$ neurons were significantly lower than those in $\mathrm{NC}$ neurons; therefore, enhanced turnover of GFR $\alpha 1$ in AD neurons cannot be considered. If this is true, mRNA levels of GFR $\alpha 1$ in $\mathrm{AD}$ neurons should be higher than those in NC neurons, which was not the case. In addition, since enhanced turnover generally became depressed over time in cultures, the differences between mRNA and protein levels of NC and AD neurons should have become smaller in this case; however, in fact, the differences became larger over time in our neuron cultures. Treatment with GDNF increased the mRNA and protein levels of GFR $\alpha 1$ in NC neurons, while those in $\mathrm{AD}$ neurons remained stable, suggesting that mRNA expression and protein production of GFR $\alpha 1$ were enhanced in NC neurons, but were not increased in the turnover of AD neurons.

Surprisingly, our primary neurons were partly alive, but they were, of course, sick; in particular, $\mathrm{AD}$ neurons were less healthy and less responsive. $\mathrm{AD}$ neurons were dying or degenerating. Under in vitro isolation, treating with papain and complicated purification procedures from brain samples, $\mathrm{AD}$ neurons are thought to be more vulnerable than NC neurons. Basically, they were taken from autopsied aged and sick brains of AD patients. As one of the mechanisms underlying cell vulnerability, we found and demonstrated selective reduction of GFR $\alpha 1$ in neurons, probably induced by $\mathrm{AD}$-related pathology, such as enhanced glutamate neurotoxicity.

Why were the levels of GFR $\alpha 1$ expression not increased, even when GDNF was added to AD neurons? Our present study suggests that glutamatergic neurotransmission may participate in the reduced expression levels of GFR $\alpha 1$ in $\mathrm{AD}$ neurons. In our neurons, $\sim 70-75 \%$ were positive for GluRN1 and GluRA2/4. This was confirmed by immunocytochemistry in the present study. When the AMPA receptor blocker CNQX or the NMDA receptor blocker AP-5 was added to uninfected AD neurons in advance, the levels of GFR $\alpha 1$ expression were increased by GDNF treatment. By contrast, GDNF treatment did not enhance the levels of GFR $\alpha 1$ expression in uninfected NC neurons when CNQX or AP5 was added in advance. These results suggest that, in $\mathrm{AD}$ neurons, there is an excess of glutamatergic neurotransmission, which may chronically reduce GFR $\alpha 1$ expression. There is clinical and laboratory evidence of excessive glutamate receptor activity in the $\mathrm{AD}$ brain, which is possibly involved in $\mathrm{A} \beta$ induced neuronal death (Mattson et al., 1992; Lipton, 2005). This receptor activity possibly remains excessive in $\mathrm{AD}$ neurons in vitro, regardless of whether $\mathrm{A} \beta$ or glutamate is increased in culture medium.

Once excess glutamatergic neurotransmission has been settled down by CNQX or AP-5 in vitro, GDNF is expected to increase GFR $\alpha 1$ expression, even in $\mathrm{AD}$ neurons. Our neurons were seeded at the same density $\left(5 \times 10^{5} / \mathrm{ml}\right)$ in $\mathrm{NC}$ and $\mathrm{AD}$ neuron cultures at the beginning. As described above, our neuron cultures contained $\sim 9 \%$ astrocytes identified by anti-GFAP, with no differences between NC and AD neuron cultures. Our neurons were cultured in serum-free Neurobasal A with B27, and subsequently the conditioned medium of neuron cultures treated with GDNF or $\mathrm{KCl}$ was processed to measure glutamate and aspartate release, revealing no differences in the release between $\mathrm{NC}$ and $\mathrm{AD}$ neuron cultures (unpublished data; $n=6$ for each), which might be due to the in vitro dissociated neuron-rich cultures. In the reality of in vivo conditions of $\mathrm{AD}$, an excess amount of extracellular glutamate may be contributed not only by neurons, but also by astrocytes, microglial cells, and furthermore by cerebral vascular cells (i.e., endothelial cells). Here we indeed observed that the response to GDNF treatment with blockage of glutamatergic neurotransmission was different between $\mathrm{NC}$ and $\mathrm{AD}$ neurons in vitro. This is possibly due to treatment with glutamate receptor blockers, which may block intracellular signals for glutamatergic neurotransmission that have already shifted to being toxic or detrimental to AD neurons, while, in NC neurons, CNQX and AP-5 may inhibit intracellular signals that have already shifted to being beneficial or trophic. This different change in signal transduction may lead to differences in the GDNFinduced GFR $\alpha 1$ expression. The different responses to GDNF show that it is irrelevant whether glutamate is increased in the medium of $\mathrm{AD}$ neuron cultures.

We found here that GDNF enhanced the survival of NC neurons infected with $\alpha 1$-NCAM, an alternative signaling receptor for GDNF, but not with RET. Generally, GDNF uses RETindependent pathways, particularly in cortical neurons (Paratcha et al., 2003); however, recently, RET was reported to be involved in axon guidance signals (Bonanomi et al., 2012). It is unlikely that, in our cortical neurons, RET is involved in GDNF-enhanced survival.

Artemin, one of the four structurally related members of GDNF family ligands (Rosenthal, 1999), is known to support the differentiation and survival of neuronal populations (Baloh et al., 1998). Studies have suggested artemin to be a NTF for midbrain dopaminergic neurons (Zihlmann et al., 2005), whereas the specific function of artemin in other brain regions is not yet known. We demonstrated herein the trophic effects of artemin on aged human cortical neurons. Biochemical experiments have shown that artemin preferentially binds to GFR $\alpha 3$ in general: this binding specificity has largely been studied for the receptor complex consisting of RET and one of four GFR $\alpha$ subtypes (Rosenthal, 1999; Sariola and Saarma, 2003; Wang et al., 2006). In the case of $\alpha 1$-NCAM as an alternative GFR $\alpha$ partner, it remains to be determined whether artemin signals through GFR $\alpha 1$ or GFR $\alpha 3$ to elicit biological effects on aged cortical neurons. Herein we demonstrated that, similar to the effects of GDNF (Schmutzler et al., 2011), artemin increased the expression levels of GFR $\alpha 1$, not GFR $\alpha 2$, GFR $\alpha 3$, or GFR $\alpha 4$; this effect was dose and time dependent, and $20-30 \mathrm{ng} / \mathrm{ml}$ artemin was enough to elicit an effect on GFR $\alpha 1$, indicating its specific effect (Schmutzler et al., 2011). Artemin, as well as GDNF, promoted cell survival and neurite extension of $\mathrm{AD}$ neurons when they were infected with GFR $\alpha 1$, but not with the corresponding empty vectors. These results sug- 
gest that artemin elicits its trophic effects on cortical neurons through receptor complex, including GFR $\alpha 1$.

\section{References}

Abe K, Saito H (1998) Amyloid $\beta$ protein inhibits cellular MTT reduction not by suppression of mitochondrial succinate dehydrogenase but by acceleration of MTT formazan exocytosis in cultured rat cortical astrocytes. Neurosci Res 31:295-305. CrossRef Medline

Akiyama H, Kaneko T, Mizuno N, McGeer PL (1990) Distribution of phosphate-activated glutaminase in the human cerebral cortex. J Comp Neurol 297:239-252. CrossRef Medline

Allen SJ, Watson JJ, Shoemark DK, Barua NU, Patel NK (2013) GDNF, NGF and BDNF as therapeutic options for neurodegeneration. Pharmacol Ther 138:155-175. CrossRef Medline

Alzheimer's Association, Thies W, Bleiler L (2011) Alzheimer's Association Report. 2011 Alzheimer's disease facts and figures. Alzheimers Dement 7:208-244. CrossRef Medline

Arenas E (1996) GDNF, a multispecific neurotrophic factor with potential therapeutic applications in neurodegenerative disorders. Mol Psychiatry 1:179-182. Medline

Baloh RH, Tansey MG, Lampe PA, Fahrner TJ, Enomoto H, Simburger KS, Leitner ML, Araki T, Johnson EM Jr, Milbrandt J (1998) Artemin, a novel member of the GDNF ligand family, supports peripheral and central neurons and signals through the GFRalpha3-RET receptor complex. Neuron 21:1291-1302. CrossRef Medline

Beach TG, Sue LI, Walker DG, Roher AE, Lue L, Vedders L, Connor DJ, Sabbagh MN, Rogers J (2008) The Sun Health Research Institute Brain Donation Program: description and experience, 1987-2007. Cell Tissue Bank 9:229-245. CrossRef Medline

Blaheta RA, Beecken WD, Engl T, Jonas D, Oppermann E, Hundemer M, Doerr HW, Scholz M, Cinatl J (2004) Human cytomegalovirus infection of tumor cells downregulates NCAM (CD56): a novel mechanism for virus-induced tumor invasiveness. Neoplasia 6:323-331. CrossRef Medline

Bonanomi D, Chivatakarn O, Bai G, Abdesselem H, Lettieri K, Marquardt T, Pierchala BA, Pfaff SL (2012) Ret is a multifunctional coreceptor that integrates diffusible- and contact-axon guidance signals. Cell 148:568582. CrossRef Medline

Braak H, Braak E (1991) Neuropathological stageing of Alzheimer-related changes. Acta Neuropathol 82:239-259. CrossRef Medline

Chang S, Rathjen FG, Raper JA (1987) Extension of neurites on axons is impaired by antibodies against specific neural cell surface glycoproteins. J Cell Biol 104:355-362. CrossRef Medline

Hardy J (2009) The amyloid hypothesis for Alzheimer's disease: a critical reappraisal. J Neurochem 110:1129-1134. CrossRef Medline

Hardy J, Selkoe DJ (2002) The amyloid hypothesis of Alzheimer's disease: progress and problems on the road to therapeutics. Science 297:353-356. CrossRef Medline

He P, Zhong Z, Lindholm K, Berning L, Lee W, Lemere C, Staufenbiel M, Li R, Shen Y (2007) Deletion of tumor necrosis factor death receptor inhibits amyloid beta generation and prevents learning and memory deficits in Alzheimer's mice. J Cell Biol 178:829-841. CrossRef Medline

Hendry SH, Schwark HD, Jones EG, Yan J (1987) Numbers and proportions of GABA-immunoreactive neurons in different areas of monkey cerebral cortex. J Neurosci 7:1503-1519. Medline

Huang Y, Mucke L (2012) Alzheimer mechanisms and therapeutic strategies. Cell 148:1204-1222. CrossRef Medline

Imbimbo BP, Panza F, Frisardi V, Solfrizzi V, D'Onofrio G, Logroscino G, Seripa D, Pilotto A (2011) Therapeutic intervention for Alzheimer's disease with $\gamma$-secretase inhibitors: still a viable option? Expert Opin Investig Drugs 20:325-341. CrossRef Medline

Iwase T, Jung CG, Bae H, Zhang M, Soliven B (2005) Glial cell line-derived neurotrophic factor-induced signaling in Schwann cells. J Neurochem 94:1488-1499. CrossRef Medline

Kanegae Y, Makimura M, Saito I (1994) A simple and efficient method for purification of infectious recombinant adenovirus. Jpn J Med Sci Biol 47:157-166. CrossRef Medline

Kaneko T, Urade Y, Watanabe Y, Mizuno N (1987) Production, characterization, and immunohistochemical application of monoclonal antibodies to glutaminase purified from rat brain. J Neurosci 7:302-309. Medline
Kasashima S, Kawashima A, Muroishi Y, Futakuchi H, Nakanishi I, Oda Y (1999) Neurons with choline acetyltransferase immunoreactivity and mRNA are present in the human cerebral cortex. Histochem Cell Biol 111:197-207. CrossRef Medline

Konishi Y, Lindholm K, Yang LB, Li R, Shen Y (2002) Isolation of living neurons from human elderly brains using the immunomagnetic sorting DNA-linker system. Am J Pathol 161:1567-1576. CrossRef Medline

Levine ES, Crozier RA, Black IB, Plummer MR (1998) Brain-derived neurotrophic factor modulates hippocampal synaptic transmission by increasing $N$-methyl-D-aspartic acid receptor activity. Proc Natl Acad Sci U S A 95:10235-10239. CrossRef Medline

Lipton SA (2005) The molecular basis of memantine action in Alzheimer's disease and other neurologic disorders: low-affinity, uncompetitive antagonism. Curr Alzheimer Res 2:155-165. CrossRef Medline

Lozano AM, Schmidt M, Roach A (1995) A convenient in vitro assay for the inhibition of neurite outgrowth by adult mammalian CNS myelin using immortalized neuronal cells. J Neurosci Methods 63:23-28. CrossRef Medline

Mattson MP, Cheng B, Davis D, Bryant K, Lieberburg I, Rydel RE (1992) $\beta$-amyloid peptides destabilize calcium homeostasis and render human cortical neurons vulnerable to exciyoyoxicity. J Neurosci 12:376-389. Medline

Mirra SS, Heyman A, McKeel D, Sumi SM, Crain BJ, Brownlee LM, Vogel FS, Hughes JP, van Belle G, Berg L (1991) The Consortium to Establish a Registry for Alzheimer's Disease (CERAD). Part II. Standardization of the neuropathologic assessment of Alzheimer's disease. Neurology 41:479486. CrossRef Medline

Mitchell PJ, Hanson JC, Quets-Nguyen AT, Bergeron M, Smith RC (2007) A quantitative method for analysis of in vitro neurite outgrowth. J Neurosci Methods 164:350-362. CrossRef Medline

Miyake S, Makimura M, Kanegae Y, Harada S, Sato Y, Takamori K, Tokuda C, Saito I (1996) Efficient generation of recombinant adenoviruses using adenovirus DNA-terminal protein complex and a cosmid bearing the full-length virus genome. Proc Natl Acad Sci U S A 93:1320-1324. CrossRef Medline

National Institute on Aging, and Reagan Institute Working Group on Diagnostic Criteria for the Neuropathological Assessment of Alzheimer's Disease (1997) Consensus recommendations for the postmortem diagnosis of Alzheimer's disease. Neurobiol Aging 18:S1-S2. Medline

Nicole O, Ali C, Docagne F, Plawinski L, MacKenzie ET, Vivien D, Buisson A (2001) Neuroprotection mediated by glial cell line-derived neurotrophic factor: involvement of a reduction of NMDA-induced calcium influx by the mitogen-activated protein kinase pathway. J Neurosci 21:3024-3033. Medline

Paratcha G, Ledda F, Ibáñez CF (2003) The neural cell adhesion molecule NCAM is an alternative signaling receptor for GDNF family ligands. Cell 113:867-879. CrossRef Medline

Ramaswamy S, Soderstrom KE, Kordower JH (2009) Trophic factors therapy in Parkinson's disease. Prog Brain Res 175:201-216. CrossRef Medline

Rosenthal A (1999) The GDNF protein family: gene ablation studies reveal what they really do and how. Neuron 22:201-203. CrossRef Medline

Sakakibara S, Okano H (1997) Expression of neural RNA-binding proteins in the postnatal CNS: implications of their roles in neuronal and glial cell development. J Neurosci 17:8300-8312. Medline

Sariola H, Saarma M (2003) Novel functions and signalling pathways for GDNF. J Cell Sci 116:3855-3862. CrossRef Medline

Savoca R, Ziegler U, Sonderegger P (1995) Effects of L-serine on neurons in vitro. J Neurosci Methods 61:159-167. CrossRef Medline

Schmutzler BS, Roy S, Pittman SK, Meadows RM, Hingtgen CM (2011) Ret-dependent and Ret-independent mechanisms of Gfl-induced sensitization. Mol Pain 7:22. CrossRef Medline

Schnell SA, Staines WA, Wessendorf MW (1999) Reduction of lipofuscinlike autofluorescence in fluorescently labeled tissue. J Histochem Cytochem 47:719-730. CrossRef Medline

Seabrook GR, Ray WJ, Shearman M, Hutton M (2007) Beyond amyloid. The next generation of Alzheimer's disease therapeutics. Mol Interv 7:261-270. CrossRef Medline

Siegel GJ, Chauhan NB (2000) Neurotrophic factors in Alzheimer's and Parkinson's disease brain. Brain Res Brain Res Rev 33:199-227. CrossRef Medline

Treanor JJ, Goodman L, de Sauvage F, Stone DM, Poulsen KT, Beck CD, Gray 
C, Armanini MP, Pollock RA, Hefti F, Phillips HS, Goddard A, Moore MW, Buj-Bello A, Davies AM, Asai N, Takahashi M, Vandlen R, Henderson CE, Rosenthal A (1996) Characterization of a multicomponent receptor for GDNF. Nature 382:80-83. CrossRef Medline

Wahlestedt C, Salmi P, Good L, Kela J, Johnsson T, Hökfelt T, Broberger C, Porreca F, Lai J, Ren K, Ossipov M, Koshkin A, Jakobsen N, Skouv J, Oerum H, Jacobsen MH, Wengel J (2000) Potent and nontoxic antisense oligonucleotides containing locked nucleic acids. Proc Natl Acad Sci U S A 97:5633-5638. CrossRef Medline

Walton KM (1999) GDNF: a novel factor with therapeutic potential for neurodegenerative disorders. Mol Neurobiol 19:43-59. CrossRef Medline
Wang X, Baloh RH, Milbrandt J, Garcia KC (2006) Structure of artemin complexed with its receptor GFR $\alpha 3$ : convergent recognition og glial cell line-derived neurotrophic factors. Structure 14:1083-1092. CrossRef Medline

Weissmiller AM, Wu C (2012) Current advances in using neurotrophic factors to treat neurodegenerative disorders. Transl Neurodegener 1:14. CrossRef Medline

Zihlmann KB, Ducray AD, Schaller B, Huber AW, Krebs SH, Andres RH, Seiler RW, Meyer M, Widmer HR (2005) The GDNF family members neurturin, artemin and persephin promote the morphological differentiation of cultured ventral mesencephalic dopaminergic neurons. Brain Res Bull 68:42-53. CrossRef Medline 